[論文]

\title{
不均一温度場における熱伝導率測定方法 Measurement Method of Thermal Conductivity in Ununiformed Temperature Field
}

\author{
大村高弘 ${ }^{*}$ ，Tseng-Wen Lian**，近藤 光**，早坂 良*，内藤牧男 ${ }^{* *}$ \\ Takahiro Ohmura*, Tseng-Wen Lian ${ }^{* *}$, Akira Kondo ${ }^{* *}$, Ryo Hayasaka*, and Makio Naito**
}

近年, ナノ粒子断熱材や真空断熱材などの高性能断熱材の実用化が進み, 工業炉や建築材料, 家電製品, 保温·保冷ボックスなど，様々な分野へ普及されるようになった。しかしながら，それらの熱伝導率を測 定することは非常に難しく，また高価な装置を必要としている．その原因の一つが，フーリエ則を適用す るために，一様な温度勾配を試験体内全域に作り出さなければならないことにある。そこで，不均一な温 度勾配が一部に存在するような温度場でも測定可能な方法を提案し, 単純で安価な熱伝導率測定装置の実 現を試みた。本方法は，既に保櫵熱板法の測定精度向上のために提案されているが，今回，試験体を一枚 のヒータで加熱するという単純な構造に対しても適用し，セラミックスファイバー断熱材とナノ粒子断熱 材の熱伝導率を測定した，その結果，既往の研究結果に対して $\pm 10 \%$ 以内で一致する值が得られた.

Recently, the practical use of high performance insulation materials such as nanoparticles insulation material or the vacuum insulation material has been spreading to various kinds of industrial fields including industrial furnaces, buildings, home electric appliances, thermal or cold insulation boxes. However, it is very difficult to measure the thermal conductivity. For this purpose, uniform temperature gradient for applying Fourier's low must be achieved in the test specimen. To solve this issue, we have proposed a new method to measure the thermal conductivity of specimens which includes ununiformed temperature gradient areas, and have developed the cheaper apparatus with simple structure. This method had been already applied for the GHP method to achieve its high accuracy. In this paper, we have applied it for the simple structure apparatus, which heated one board with a pair of heaters. As the result, the thermal conductivity of ceramics fiber insulation and the nanoparticles insulation material agreed within $\pm 10 \%$ for the previous studies.

[Keywords: GHP, thermal conductivity, thermal insulation, Fourier's low]

\section{1. 緒言}

近年の著しい産業発展の一方で, 地球温暖化やエネルギ一資 源の枯渇など，地球規模のエネルギー問題がクローズアップ されてきている. そのため, 世界的な規模で様々な省エネルギ 一活動が行われるようになってきた. 特に, 自動車や鉄鋼, 電 子部品, 半導体, 窯業など, 高温度領域で製造するような工程 を持つ産業分野では熱源からの熱損失を如何に減らすかとい う研究開発が盛んに行われている. そこでは, これらの熱源を 断熱することが非常に重要な課題となり，断熱材のさらなる 性能向上が求められている.このような断熱材の開発に欠か せない役割を果たしているのが熱伝導率の精密な測定である。

* 和歌山工業高等専門学校 知能機械工学科, $\bar{T} 644-0023$ 御坊市名 田町野島 77. RD Dept. Intelligent Mechanical Engineering, National Institute of Technology, Wakayama College, 77 Nojima Nada Gobou 644-0023. TEL: +81-738-29-8345

E-mail: oomura@wakayama-nct.ac.jp

** 大阪大学 接合科学研究所附属スマートプロセス研究センタ 一， テ567-0047 茨木市美穂ヶ丘 11-1. Smart Processing Research Center, Joining and Welding Research Institute, Osaka University. 11-1, Mihogaoka, Ibaraki, Osaka 567-0047, E-mail: m-naito@jwri. osaka u.ac.jp
熱伝導率は, 断熱材の断熱性能の指標の一つであり,これを如 何に低減させ，熱損失を減らすことができるかが省エネルギ 一に大きく関わっている. 熱伝導率をより正確に測定し, 開発 段階で，温度やかさ密度等のパラメータとの関係を把握する ことが重要である.

断熱材の熱伝導率測定には, 主に定常法が用いられ, 保護熱 板法 (Guarded HotPlate method: GHP 法) [1]や平板熱流計法 [2] などが主流となっている．特に GHP 法は広く使用され，標準 的な測定方法として位置付けられている. また, 非定常熱線法 も使用されることが多く，これは通常の非定常法のように熱 拡散率を測定するのではなく，熱伝導率を直接測定すること ができ，しかも断熱材よりも高い熱伝導率を持った材料の測 定が可能であるため, 特にレンガ類の測定に使用されている. 定常法による測定原理に基づく熱伝導率測定装置では，フ ーリエの法則を適用するために，試験体内部に一様な温度勾 配を作り出しているが，これを実現するために，非常に複雑な 構造となっている．例えば GHP 法では，試験体の高温面側と 接触するヒータを主熱板と保護熱板に分離する構造をとって いる.これが, 試験体内部の特定の部分における温度勾配を均 
一にしているが, その結果, 構造が複雑となり, 温度制御も複 雑となっている. それ故, 非常に高価な装置となり, 測定技術 の普及の障壁となっている. そこで, 試験体内部に不均一な温 度勾配の部分が存在するような温度場でも測定可能な方法を 提案し，単純な構造で安価な熱伝導率測定装置の実現を試み た.ここで検討した測定方法は，既に GHP 法の測定精度向上 のために考案されているが[3], 今回, 複雑な構造を持たない ヒータで加熱する構造に適用し，その妥当性を確認した。

\section{2. 試験体厚さ方向の熱伝導率測定方法}

本研究で提案する測定方法を以下に示す.

図 1 に示寸ように, ヒータ 1 とヒータ 2 の温度が等しくな る $\left(\theta_{h 1}=\theta_{h 2}\right)$ ようにヒータ 2 の温度を制御すると, ヒータ 1 で 発生した熱量 $Q$ が全て試験体内に流入すると仮定できる.さ らに，その熱量 $Q$ が，試験体の厚さ方向（低温側へ向から方 向）に流れる熱量 $Q_{t}$ と，試験体内部で厚さ方向以外の方向一 放散する熱量 $Q_{\text {loss }}$ の和になっていると仮定すると，

$$
Q=Q_{t}+Q_{\text {loss }}
$$

と表すことができる.

また，試験体の厚さ方向を通過する熱量 $Q_{t}$ に対しては，フ ーリエの法則が適用できると仮定して，

$$
Q_{t}=\lambda_{t} \frac{\Delta \theta}{d} S
$$

とする. ここで, $d$ は試験体の厚さ $[\mathrm{m}], Q_{t}$ は試験体を厚さ方 向に通過寸る熱量[W], $S$ は熱流通過面積 $\left[\mathrm{m}^{2}\right], \Delta \theta$ は試験体の 温度差 $\left(=\theta_{h 1}-\theta_{h 3}\right)\left[{ }^{\circ} \mathrm{C}\right], \lambda_{t}$ は試験体の厚さ方向の熱伝導率 $[\mathrm{W} /(\mathrm{m} \cdot \mathrm{K})]$ である.

一方，ヒータ 1 から試験体一流入する熱量 $Q$ については, $Q$ がフーリエの法則と同じ形の式で表されるものとして, 温 度勾配 $\Delta \theta / d$ と熱流面積 $S$ に対して比例すると仮定し，その係 数を元とすれば,

$$
Q=\lambda_{c} \frac{\Delta \theta}{d} S
$$

と表すことができる.ここで， $\lambda_{c}$ の単位は[W/(m·K)]である.

さらに熱損失 $Q_{\text {loss }}$ は，面内方向に生じる代表温度差を $\Delta \theta_{\text {loss }}$ と寸れば，面内方向の熱コンダクタンス $H$ との積で表され，

$$
Q_{\text {loss }}=H \cdot \Delta \theta_{\text {loss }}
$$

となる. 式(1)に式(2)から式(4)を代入することで,

$$
\lambda_{c}=\lambda_{t}+a \cdot \Theta
$$

を得る.ここで, 係数 $a$ を式(6)のようにおき，また，試験体の

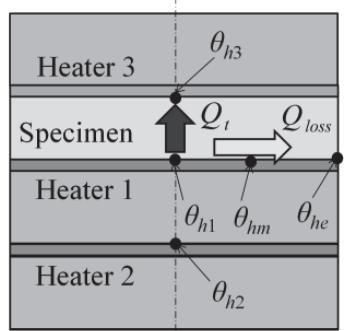

Fig. 1 Cross section of measurement system

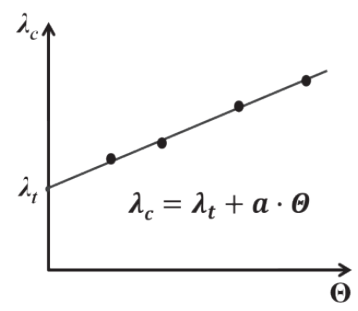

Fig. 2 Image of proposed measurement method
厚さ方向の温度差に対する面内方向の代表温度差との比を式 (7)に示す $\Theta$ (無次元温度) で表した.

$$
a=\frac{H \cdot d}{S} \quad(6) \quad \Theta=\frac{\Delta \theta_{l o}}{\Delta \theta}
$$

式(5)より, 無次元温度 $\Theta$ と係数 $\lambda_{c}$ は直線的な関係をもつこ とが分かる. 本測定方法では, 試験体上下の温度差 $\Delta \theta$ を複数 回変化させて式(3)に示寸係数 $\lambda_{c}$ を測定し，そのときの試験体 表面の温度分布から $\Delta \theta_{\text {loss }}$ を求めて無次元温度 $\Theta$ を導き, 横軸 に無次元温度 $\Theta$, 縦軸に式(3)の係数 $\lambda_{c}$ をプロットして近似直 線を描く. その直線の切片が, 試験体の厚さ方向の熱伝導率 $\lambda_{t}$ となる. 図 2 にデータをプロットしたイメージを示す.この測 定方法では，熱損失が最も大きいと考えられる面内の温度分 布を測定することが好ましく，本測定系では図 1 に示すヒ一 夕 1 と試験体との接触面の温度分布を測定した.

面内方向の温度差 $\Delta \theta_{\text {loss }}$ にいては, 平面内の温度分布関数 $f(r)$ を決定し，これを使って面内平均温度を求め, 高温面中央 における温度 $\theta_{h 1}$ との差をとることで $\Delta \theta_{\text {lass }}$ を決定した. 高温 面の中央を原点にとり, その平面内の温度分布を測定する. そ のときの原点から傾までの範囲における平均温度 $\theta_{h m}$ は,

$$
\theta_{h m}=\frac{1}{r_{e}} \int_{0}^{r_{e}} f(r) d r
$$

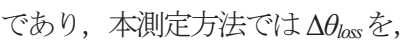

$$
\Delta \theta_{\text {loss }}=\theta_{h 1}-\theta_{h m}
$$

とした. 実際の測定では, 温度分布関数 $f(r)$ として三次曲線を 使用した. ここで, 試験体が円盤であるか立方体形状であるか で分布関数も異なってくる. 特に, 立方体の場合は, 中心から ぞの辺へ向から直線状の温度分布関数をとるかで，その様子 が異なるはずである. しかしながら, どの線上の分布関数を使 って $\Delta \theta_{\text {loss }}$ を決定しても，式(5)に示すように切片 $\lambda_{t}$ に変化はな い. したがって，どのような試験体形状であっても，熱損失の

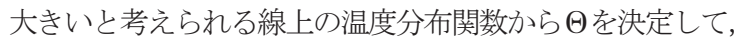
厚さ方向の熱云導率 $\lambda_{t}$ を決定できることになる.

本研究では, 以上2.で提案した測定方法の妥当性を, 以下に 報告するシミュレーションと自作した測定装置による測定結 果を用いて検討した. シミュレーションでは, 測定系内部の温 
度場を計算し, その温度場から本方法て熱伝導率 $\lambda_{t}$ を求め, シ ミュレーションのために設定した試験体の熱伝導率 $\lambda_{s}$ との比 較によって本測定方法の精度を検討した. また，自作装置によ る測定では, 得られた結果と既往の研究結果とを比較し, 両者 の差を検討した。

\section{3. シミュレーションによる測定精度の検討}

2.で提案した測定方法を実際の装置に適用する前に, シミュ レーションにより測定精度の確認を行った，その際，式(9)に 示寸 $\Delta \theta_{\text {loss }}$ 以外に, 図 1 に示寸ように, $\theta_{h 1}$ と試験体の高温面端 部 (高温面の縁) の温度 $\theta_{h e}$ との差, $\theta_{h e}$ と試験体の周囲を取り 巻く空気温度 $\theta_{a i r}$ との差を使った場合の測定精度なども検討し た.

\section{1 シミュレーション方法}

三次元座標系 $(x, y, z)$ における熱的に等方な材料の定常熱伝 導方程式は, 次式で与えられる.

$$
\lambda\left(\frac{\partial^{2} \theta}{\partial x^{2}}+\frac{\partial^{2} \theta}{\partial y^{2}}+\frac{\partial^{2} \theta}{\partial z^{2}}\right)+Q=0
$$

ここで, $Q$ は単位体積当たりの発熱量, $\theta$ は温度, $\lambda$ は熱伝導 率である.この式を差分化すると，

$$
\theta_{i, j, k}=\frac{\frac{\theta_{i+1, j, k}+\theta_{i-1, j, k}}{\Delta x^{2}}+\frac{\theta_{i, j+1, k}+\theta_{i, j-1, k}}{\Delta y^{2}}+\frac{\theta_{i, j, k+1}+\theta_{i, j, k-1}}{\Delta z^{2}}+\frac{Q}{\lambda}}{\left(\frac{1}{\Delta x^{2}}+\frac{1}{\Delta y^{2}}+\frac{1}{\Delta z^{2}}\right) \times 2}
$$

となる.ここで，対象とする各点（格子点）の $x$ - , $y$-, z-軸上に おける位置を識別するために，それぞれ下付の添え字 $i, j, k$ を 使った．さらに，Excel ${ }^{\mathrm{TM}}$ の Sheet 上にあるセルをその格子点 と見なし, かつ単位図形 (四角形) として, 測定系の立体図 形を描いた. そして，各セルに式(11)を代入し連立方程式と して解いた[4].

\section{2 シミュレーション条件}

本シミュレーションでは, 図 1 に示寸構造の測定系を対象

Table 1 Dimension and thermal conductivity of each part.

\begin{tabular}{|c|c|c|c|c|}
\hline & $x[\mathrm{~mm}]$ & $y[\mathrm{~mm}]$ & $z[\mathrm{~mm}]$ & $\lambda[\mathrm{W} /(\mathrm{m} \cdot \mathrm{K})]$ \\
\hline Specimen & 305 & 304 & 30 & Arbitrary value \\
\hline Heater 1 & 305 & 304 & 12 & 13.4 \\
\hline Insulation 1 & 305 & 304 & 39.95 & 0.03 \\
\hline Heater 2 & 305 & 304 & 12 & 13.4 \\
\hline Insulation 2 & 305 & 304 & 39.95 & 0.03 \\
\hline Heater 3 & 305 & 304 & 2 & 13.4 \\
\hline Insulation 3 & 305 & 304 & 39.95 & 0.03 \\
\hline
\end{tabular}

Table 2 Dimension of a cell in each part.

\begin{tabular}{|c|c|c|c|}
\hline & $\Delta x[\mathrm{~m}]$ & $\Delta y[\mathrm{~m}]$ & $\Delta z[\mathrm{~m}]$ \\
\hline Specimen & 0.005 & 0.003 & 0.005 \\
\hline Heater 1 & 0.005 & 0.004 & 0.005 \\
\hline Insulation 1 & 0.005 & 0.005 & 0.005 \\
\hline Heater 2 & 0.005 & 0.004 & 0.005 \\
\hline Insulation 2 & 0.005 & 0.005 & 0.005 \\
\hline Heater 3 & 0.005 & 0.0007 & 0.005 \\
\hline Insulation 3 & 0.005 & 0.005 & 0.005 \\
\hline
\end{tabular}

とした. 各部の寸法と熱伝導率を表 1 に示す. 気体と固体壁に おける熱伝達率を $8 \mathrm{~W} /(\mathrm{m} \cdot \mathrm{K})$ とし, 周囲の空気の温度を $25^{\circ} \mathrm{C}$ 一定とした. ヒータの電気抵抗は, 実際に使用するヒータのそ れと同じく $37.5 \Omega$ とした. Excel ${ }^{\mathrm{TM}}$ の Sheet 上における各部分 のセル一つ分の寸法を表 2 に示す.ここで, 測定装置と同じサ イズになるように寸法を決めた。

\section{3 無次元温度 $\Theta$ の決定方法}

本シミュレーションでは, まず試験体の熱伝導率 (シミュレ ーションのために設定した熱伝導率 $\lambda_{s}$ ) を $0.05,0.08,0.14$ $[\mathrm{W} /(\mathrm{m} \cdot \mathrm{K})]$ の 3 つの゚ターンとし, それぞれに対して試験体の 厚さ方向の温度差 $\Delta \theta$ が $20^{\circ} \mathrm{C} \sim 30^{\circ} \mathrm{C}$ 範囲で変化するように 条件を設定し, 各々の温度場を計算した. その後, 前述した測 定方法により熱伝導率 $\lambda_{t}$ を算出し, 計算のために設定した值 $\lambda_{s}$ と比較した.

面内方向の代表温度差 $\Delta \theta_{\text {loss }}$ に関しては，次の 3 つのパター ンで算出し，それぞれの精度を確認した。

(1) 試験体の高温面の中心温度と面内方向の平均温度

図 1 に示すように, 試験体の高温側表面における温度分布 の平均温度 $\theta_{h m}$ (式 $\left.(8)\right)$ と中心温度 $\theta_{h 1}$ の差を $\Delta \theta_{\text {loss }}$ とし,

$$
\Delta \theta_{\text {loss }}=\theta_{h 1}-\frac{1}{145} \int_{0}^{145} f(r) d r
$$

として無次元温度 $\Theta$ を決定した. ここで， $r_{e}=145 \mathrm{~mm}$ とした が，これは周囲雰囲気の影響を強く受けないようにするため である．試験体の一辺は約 $300 \mathrm{~mm}$ であり，その半分が約 $150 \mathrm{~mm}$ となるが，セル一つ分 $(5 \mathrm{~mm})$ のデータを除き $r_{e}$ を $145 \mathrm{~mm}$ とした. このようにすることで, 近似関数 $f(r)$ の試験体 内部における温度の近似精度を向上させることができる.

(2) 試験体の高温面中心温度と端部温度

試験体の高温側表面の中心温度 $\theta_{h 1}$ と端部温度 $\theta_{h e}$ との差を $\Delta \theta_{\text {loss }}$ とした. すなわち,

$$
\Delta \theta_{\text {loss }}=\theta_{h 1}-\theta_{h e}
$$

として無次元温度 $\Theta$ を決定した，ここで， $\theta_{h e}$ は試験体の高温 面の端部温度であり, シミュレーションした温度場の試験体端 部にあるセルの温度を使用した。 


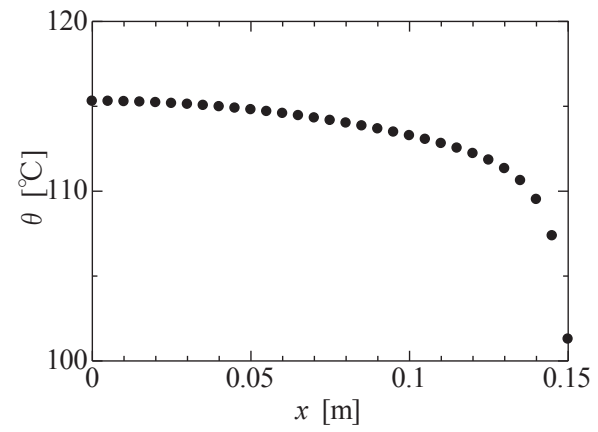

Fig. 3 An example of temperature distribution of heated surface obtained by numerical simulations

(3) 試験体の端部温度と周囲雰囲気温度

試験体の端部温度 $\theta_{h e}$ と周囲雰囲気温度 $\theta_{\text {air }}$ との差を $\Delta \theta_{\text {loss }}$ と した.すなわち,

$$
\Delta \theta_{\text {loss }}=\theta_{\text {he }}-\theta_{\text {air }}
$$

として無次元温度 $\Theta$ を決定した，ここで， $\theta_{\text {air }}$ は試験体周囲の 雰井気温度であり, $\theta_{h e}$ は 3.3 の(2)の場合と同様に, シミュレー ションした温度場の試験体端部にあるセルの温度を使用した.

図 3 に,シミュレーションで得られた試験体の高温側表面 の温度分布の一例を示す。この図より， $x$ が $130 \mathrm{~mm}$ を超えた

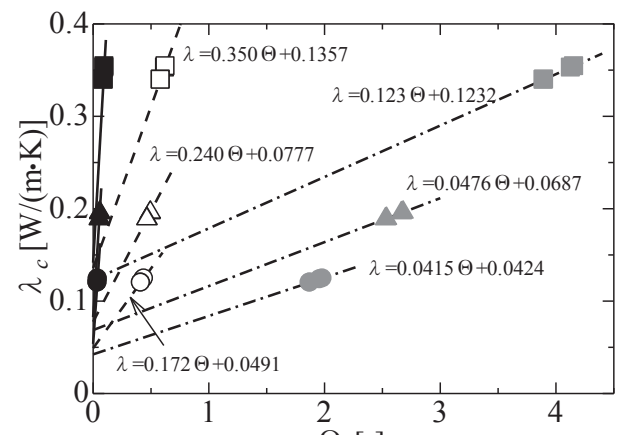

$\Theta[-]$

Fig. 4 Relation between $\Theta$ and $\lambda_{c}$ obtained by numerical simulations

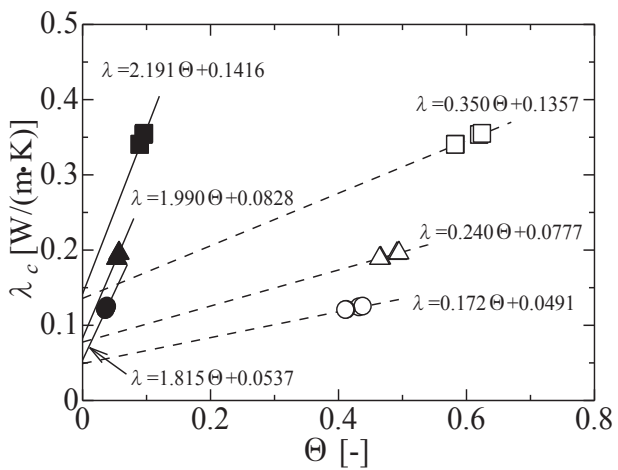

Fig. 5 Relation between $\Theta$ and $\lambda_{c}$ obtained by numerical simulations; Scaling up $\Theta$ range under 1 in Fig. 4.
あたりから急激に温度が低下していることが分かる.したがっ て，実際の測定で滑らかな温度分布関数 $f(r)$ を近似するには， 多数の温度測定点を必要とすることが分かる. そこで，シミュ レーションでは出来るだけ正確に温度分布を近似するために 6 次関数を使い, 実際の測定では測定点が少ないため 3 次関数 で温度分布を近似した。

シミュレーションで得られた温度場から求めた $\Theta$ と $\lambda_{c}$ の関 係を, 図 4 と図 5 に示す。図 5 は, 図 4 の $\Theta<1$ の範囲におけ る部分を拡大したものである.ここで，丸印，三角印，四角印 は,それぞれシミュレーションのために設定した試験体の熱伝 導率が $0.05 \mathrm{~W} /(\mathrm{m} \cdot \mathrm{K}), 0.08 \mathrm{~W} /(\mathrm{m} \cdot \mathrm{K}), 0.14 \mathrm{~W} /(\mathrm{m} \cdot \mathrm{K})$ であり, 黒色 印 (実線)，白色印 (破線)，薄色印 (一点鎖線) は，それぞれ 以下のようにして $\Delta \theta_{\text {loss }}$ を決定したことを表している.

黒色印 (実線) : $\Delta \theta_{\text {loss }}=\theta_{h 1}-\theta_{h m}$

白色印 (破線) : $\Delta \theta_{l o s s}=\theta_{h 1}-\theta_{h e}$

薄色印 (一点鎖線) : $\Delta \theta_{\text {loss }}=\theta_{\text {he }}-\theta_{\text {air }}$

いずれの設定条件についても，試験体の高温面と低温面の 温度差 $\Delta \theta$ が $20^{\circ} \mathrm{C} 30^{\circ} \mathrm{C}$ 範囲で 3 つのデータをとり，それら の結果をプロットし近似直線を求めた。

図 4 と図 5 に示す近似直線を使って得られた厚さ方向の熱 伝導率 $\lambda_{t}$ と，シミュレーションのために設定した熱伝導率 $\lambda_{s}$ との比率 $\left(1-\lambda_{t} / \lambda_{s}\right)$ を表 3 に示す。 さらに， $\lambda_{t}$ と $\lambda_{s}$ の相関四を 図 6 に示寸。ここで，丸，三角，四角印は， $\Delta \theta_{\text {loss }}$ がそれぞれ $\theta_{h 1}-\theta_{h m}, \theta_{h 1}-\theta_{h e}, \theta_{h e}-\theta_{\text {air }}$ のときの結果を示している.

表 3 と図 6 より，高温面中心温度 $\theta_{h 1}$ と高温面端部温度 $\theta_{h e}$

Table 3 Ratio of set to estimated thermal conductivities

\begin{tabular}{|c|c|c|c|}
\hline \multirow{2}{*}{$\Delta \theta_{\text {loss }}$} & \multicolumn{3}{|c|}{$1-\lambda_{\mathrm{t}} / \lambda_{\mathrm{s}} \quad[\%]$} \\
\cline { 2 - 4 } & $\lambda_{\mathrm{s}}=0.05$ & $\lambda_{\mathrm{s}}=0.08$ & $\lambda_{\mathrm{s}}=0.14$ \\
\hline$\theta_{h 1}-\theta_{h m}$ & 7.4 & 3.5 & 1.1 \\
\hline$\theta_{h 1}-\theta_{h e}$ & 1.8 & 2.9 & 3.1 \\
\hline$\theta_{h e}-\theta_{\text {air }}$ & 15.2 & 14.1 & 12.0 \\
\hline
\end{tabular}

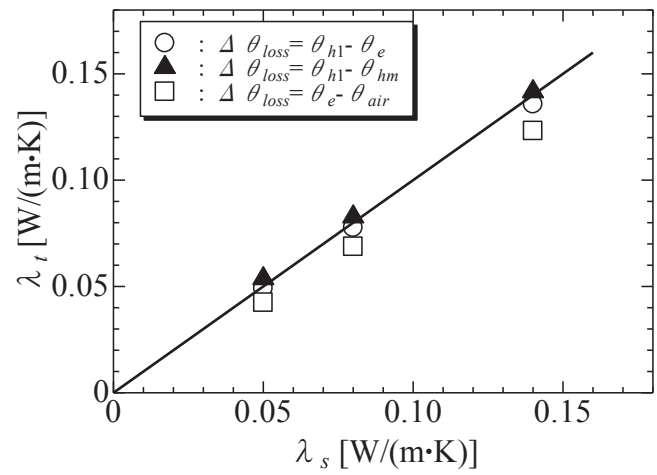

Fig. 6 Mutual relation between $\lambda_{t}$ and $\lambda_{s}$ 


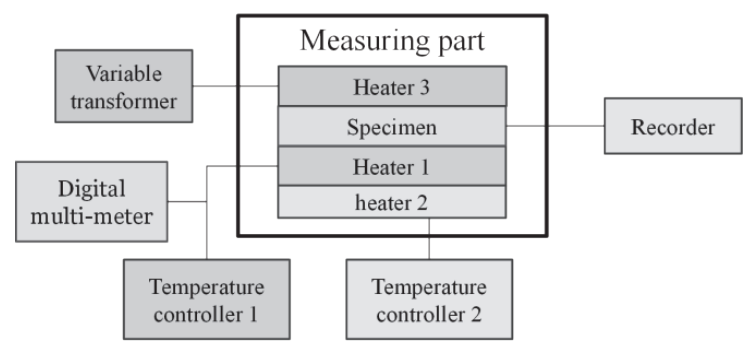

Fig. 7 Schematic diagram of new measurement system

との差を使って無次元温度 @を決定する場合が，最も測定䛊 差を小さくできることが分かる，一方，高温面端部温度 $\theta_{h e}$ と 周囲雾囲気温度 $\theta_{a i r}$ を使うと, 測定誤差が十数\%以上になるこ とが分かる.

したがって, 実際の測定でも高温面中心温度 $\theta_{h 1}$ と高温面端 部温度 $\theta_{h e}$ との差を測定して, 無次元温度 $\Theta$ を決定すべきであ る. しかしながら, 端部の温度を実際に測定することは非常に 難しく，そのため内部温度分布からの外挿による推定となる が，図 3 に示すように温度分布が端部付近で急激に変化して いるため推定誤差が大きくなってしまうと考えられる。そこ で，実際の測定では式(9)で定義したように高温面中心温度 $\theta_{h 1}$ と高温面平均温度 $\theta_{h m}$ との差を使って, 無次元温度 $\Theta$ を決定 した.

\section{4. 測定装置}

図7 に, 測定系の模式図を示寸. 装置は, 試験体の片面を加 熱するヒータ 1 とその温度を制御する温度コントローラー1, 試験体のもう一方の片面を加熱するヒータ 3 とそれに電圧を 加える変圧器 (スライダック), ヒータ 1 で発生した熱エネル ギーが試験体に対して反対の方向 (本装置では下方向) 一流れ ないようにするためのヒータ 2 とその温度を制御する温度コ ントローラー2, ヒータ 1 の出力電圧を読み取るデジタルマル チメーター (Agilent $34401 \mathrm{~A})$ ，試験体の各部の温度を記録す るデータロガー ((株)GRAPHTEC midi LOGGER GL900) から 構成されている.

図 8 に, 測定部の模式図を示す，ヒータ 1 とヒータ 2 は同 じセラミックヒータ（(株)坂口電熱 VF512A12S）であり，内 部に埋め込まれたヒータ線と断熱部分を含めた厚さは約 50 $\mathrm{mm}$ である。ヒータ 3 は厚さ約 $1 \mathrm{~mm}$ のラバーヒータ（(株)坂 口電熱 サミコン $230 \mathrm{SAM} 1530,150 \mathrm{~mm} \times 75 \mathrm{~mm})$ を 2 枚並心゙ て設置し，その上に厚さ約 $50 \mathrm{~mm}$ のケイ酸カルシウム保温材 を重ねた。ヒータ 2 の下側には, 厚さ約 $20 \mathrm{~mm}$ のスタイロフ オームを 2 枚重ねて設置した. 試験体のサイズは約 $300 \times 300$ $\mathrm{mm}$, 熱伝導率測定可能な厚さ範井は約 $10 \sim 50 \mathrm{~mm}$ である.

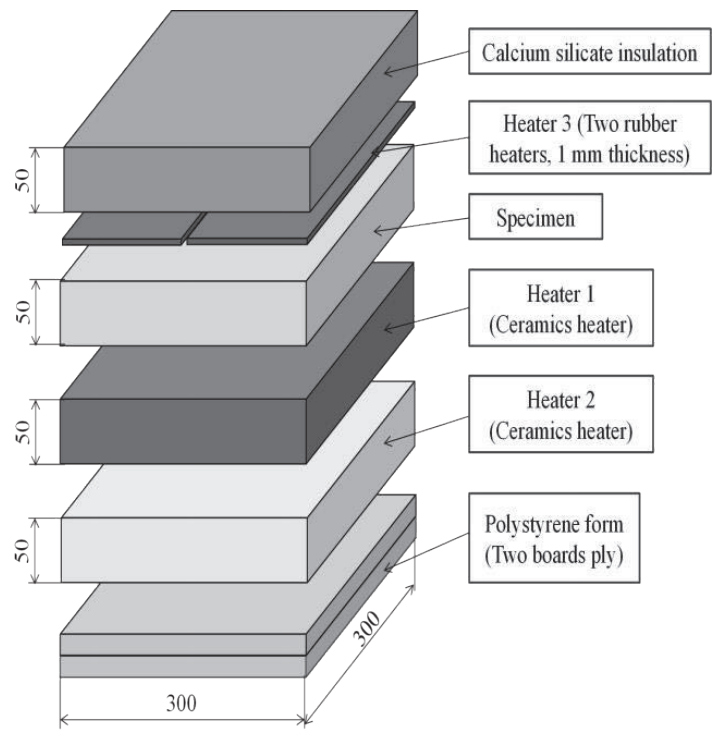

Fig. 8 Measurement part of new apparatus
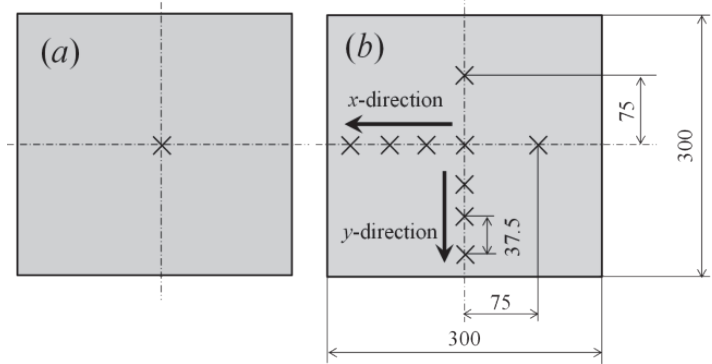

Fig. 9 Positions of thermocouples

Table 4 Test Specimen

\begin{tabular}{|c|c|c|}
\hline & Size $\left[\mathrm{mm}^{3}\right]$ & $\rho\left[\mathrm{kg} / \mathrm{m}^{3}\right]$ \\
\hline Ceramics fiber insulation & $300 \times 300 \times 27.9$ & 128 \\
\hline Fumed silica insulation & $151 \times 101 \times 11.64$ & 391 \\
\hline
\end{tabular}

図 9 に，直径 $0.32 \mathrm{~mm}$ の $\mathrm{K}$ タイプ熱電対を設置した位置を 示寸 (X印)。(a)では中心に $1 つ,(b)$ では中心から $x$ 軸方向と

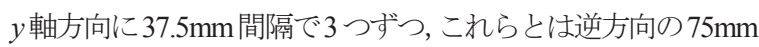
の位置に 1 つずつ，計 9 つの熱電対を配置した. 試験体の高 温面と低温面, ヒータ 1 とヒータ 2 の接触面には, 図 $9(b)$ に 示寸配置で設置し，ヒータ 2 とスタイロフォームの接触面に は図 $9(a)$ に示す配置で設置した。熱電対は，試験体の表面に 接触できるように直接配置したが，ヒータと試験体の間に隙 間が生じるのを防ぐために, ヒータの表面側に厚さ $2 \mathrm{~mm}$ 程度 のセラミックスブランケットを敷いた.

\section{5. 試験体}

セラミックファイバー断熱材, ナノ粒子断熱材の 2 種類を 


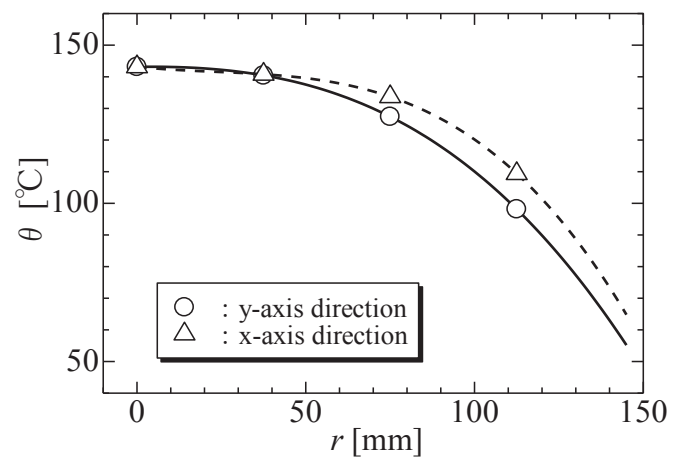

Fig. 10 Temperature distribution of high temperature surface of Ceramics fiber insulation (One measuring example)

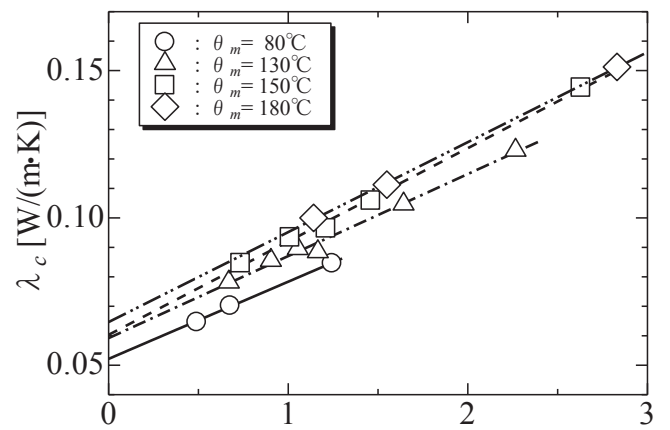

$\Theta[-]$

Fig. 11 Relation between $\Theta$ and $\lambda$ obtained by measuring Ceramics fiber insulation.

測定した. それぞれの寸法とかさ密度を表 4 に示寸. ただし， ナノ粒子断熱材に関しては，同質同形状の試験体（約 $150 \mathrm{~mm}$ $\times 100 \mathrm{~mm} ）$ を 6 つ用意し, 約 $300 \mathrm{~mm} \times 300 \mathrm{~mm}$ となるように配 置した．表に示寸值はそれら 6 つの平均值である.

\section{6. 結果と考察}

\section{1 セラミックファイバー断熱材の測定結果}

セラミックファイバー断熱材を試験体として測定した場合 の温度場の一例を図 10 に示寸。丸印は，図 9 に示寸 $y$ 軸方向 の温度分布であり, 実線は3 次方程式による近似曲線である.

一方, 三角印は, 図 9 の $x$ 軸方向の温度分布であり, 破線は同 じく 3 次方程式による近似曲線である. データは測定開始か ら約 10 時間経過した時点での温度である. 本実験では, 図 9 に示寸 $y$ 軸方向の温度分布を使って厚さ方向の熱伝導率 $\lambda_{t}$ を 算出した. $y$ 軸方向を選んだのは, 僅かだが $x$ 軸方向よりも温 度変化が大きく, より熱損失の影響が大きいと判断したため である。

図 11 に, 各温度における $\Theta$ と の関係の一例を示寸.ここ で, 丸, 三角, 四角, 菱形の印が, それぞれ $80^{\circ} \mathrm{C}, 130^{\circ} \mathrm{C}, 150^{\circ} \mathrm{C}$, $180^{\circ} \mathrm{C}$ で測定した結果を表しており, 同様に, 実線, 一点鎖線, 破線, 二点鎖線が, それぞれ試験体平均温度 $80^{\circ} \mathrm{C}, 130^{\circ} \mathrm{C}, 150^{\circ} \mathrm{C}$, $180^{\circ} \mathrm{C}$ 結果に対する近似直線を表している. また, $\theta_{m}$ は式(15) で示寸試験体の平均温度であり, 各温度差 $\Delta \theta$ で得られた試験 体のそれぞれの高温面中央温度 $\theta_{h 1}$ と低温面中央温度 $\theta_{h 3}$ の平 均值を，全平均した結果である.

$$
\theta_{m}=\frac{\sum_{m=1}^{n}\left(\theta_{h 1}+\theta_{h 3}\right)_{m} / 2}{n}
$$

ここで, $m$ は, 厚さ方向の熱伝導率 $\lambda_{t}$ を得ようとしている各温 度において，無次元温度 $\Theta$ を変えた測定一つ一つを識別する ための数字であり, $n$ はその温度における全測定回数である. 寸なわち, $n$ は $\Theta$ を変えた全回数である. 図 11 に示寸各温度 における一次直線の切片が, それぞれの温度における厚さ方 向の熱伝導率 $\lambda_{t}$ となる.

厚さ方向の熱伝導率 $\lambda_{t}$ の算出結果を図 12 に示す。丸印が今 回の結果であり, 黒三角印が既往の測定結果 (かさ密度はほぼ 同じ）[5]，実線が次式に示すセラミックファイバー断熱材に 与えられている推定式[6]である.

$$
\lambda=A \rho+\frac{B}{\rho} T^{3}+(C \cdot T+D) \cdot \lambda_{\text {air }}
$$

ここで, $A=1.1 \times 10^{-5}\left[\mathrm{~W} \cdot \mathrm{m}^{2} /(\mathrm{K} \cdot \mathrm{kg})\right], \quad B=1.3 \times 10^{-8}\left[\mathrm{~W} \cdot \mathrm{kg} /\left(\mathrm{m}^{4}\right.\right.$. $\left.\left.\mathrm{K}^{4}\right)\right], C=-4.4 \times 10^{-5}\left[\mathrm{~K}^{-1}\right], D=1.4[-], \rho=128 \mathrm{~kg} / \mathrm{m}^{3}$ である. 破線 は実線に対する $10 \%$ を示している. また, 既往の研究[5]では, 試験体の片面を加熱し，反対側の面は空気中に放熱させると いう方法で熱伝導率を測定している. 横軸の $\theta_{m}$ は, 試験体の 平均温度を示しているが，既往の研究では試験体の高温面と 低温面の平均を平均温度としている. 後述するナノ粒子断熱 材の測定結果（図 13）の横軸についても同様である.

図 12 より，3 者が大凡 $\pm 10 \%$ 以内で一致していることが分 かる. ただし, 本法で求めた $200^{\circ} \mathrm{C}$ 熱伝導率が推定式とは大

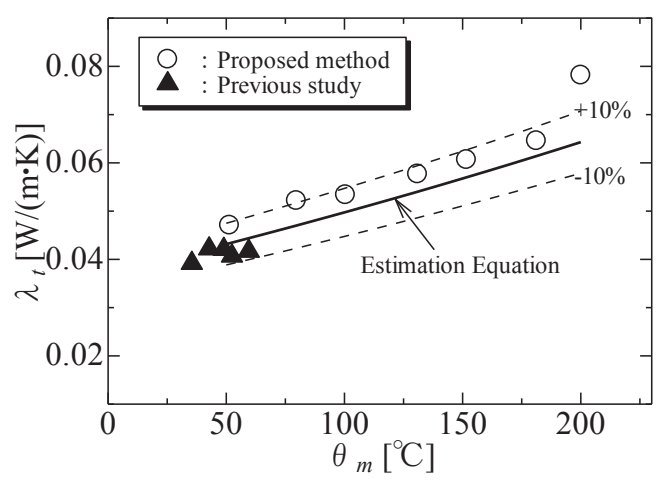

Fig. 12 Thermal conductivity of Ceramics fiber insulation 


\section{7. 結 言}

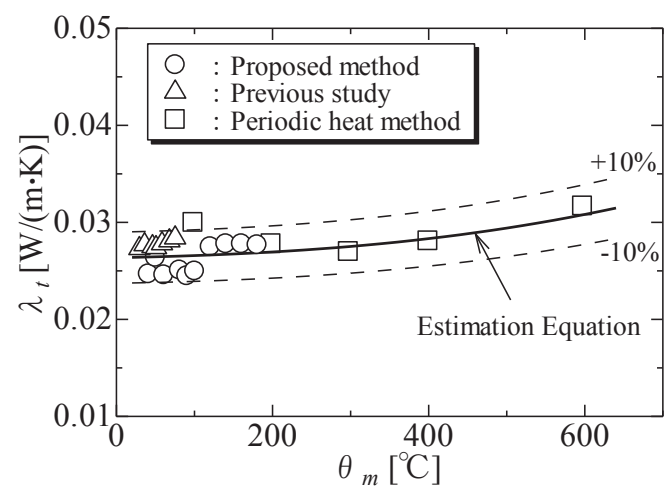

Fig. 13 Thermal conductivity of Fumed silica compact

きく外れているのも分かる.この原因は, ヒータ 3 として使用 しているラバーヒータの使用温度限界が考えられる. 使用し たラバーヒータの使用限界温度は $200^{\circ} \mathrm{C}$ であるため, $200^{\circ} \mathrm{C}$ 付 近での長時間使用では，面内温度の均一性が保たれていなか った可能性が考えられる. そのため厚さ方向の熱伝導率を適 切に測定できなかった可能性が考えられる.

\section{2 ナノ粒子断熱材の測定結果}

図 13 に, ナノ粒子断熱材の熱伝導率測定結果を示す. 丸, 三角, 四角印は, それぞれ今回の算出結果, 既往の研究結果[9], 周期加熱法による測定結果 $[7,8]$ である. なお, 今回測定した試 験体は，他の研究で使用されたものとは異なるものではある が, 同じ種類の材料を使って, 同様の条件により製作したもの であり, 形状やかさ密度もほぼ一致している.また, 実線はナ ノ粒子断熱材の熱伝導率推定式として既に提案されている次 式[7,8]を使って描かれた結果である.

$$
\lambda=A \rho+\frac{B}{\rho} T^{3}+\lambda_{g}
$$

ここで, $A=4.3 \times 10^{-5}\left[\mathrm{~W} \cdot \mathrm{m}^{2} /(\mathrm{K} \cdot \mathrm{kg})\right], \quad B=2.7 \times 10^{-8}\left[\mathrm{~W} \cdot \mathrm{kg} /\left(\mathrm{m}^{4}\right.\right.$. $\left.\left.\mathrm{K}^{4}\right)\right], \quad \lambda_{g}=0.0091[\mathrm{~W} /(\mathrm{m} \cdot \mathrm{K})], \rho=391 \mathrm{~kg} / \mathrm{m}^{3}$ であり, 破線は実線 に対する $10 \%$ を示している.係数 $A$ と $B$ の決定については, $300^{\circ} \mathrm{C}$ 以上における周期加熱法の結果を使って導いた. 一方 $\lambda_{g}$ については，試験体内部のナノ粒子が作り出す空隙に依存す るため, ナノ粒子の種類によって決まってしまう. そこで, 同 じ材料を使用していることを考慮して，今回は既往の研究で 得られた值を使用した[7-9].

図 13 より，測定方法の異なる 3 者の結果が，ほぼ士 $10 \%$ 以 内で一致していることが分かる．ただし， $100^{\circ} \mathrm{C}$ 付近で $10 \%$ を 超える結果が得られているが,これは試験体内に存在する水分 の相変化による影響であると推定される.
試験体内部の温度場の一部に，不均一な温度勾配があるよ うな条件でも熱伝導率を精度よく測定できる方法を提案した。 シミュレーションにより測定方法の妥当性と条件を検討し， 熱伝導率測定装置を試作した。 その装置を使ってセラミック ファイバー断熱材とナノ粒子断熱材の熱伝導率を測定したと ころ, 既往の研究結果と $\pm 10 \%$ 以内で一致することが分かっ た.

また, 開発した装置は, 保護熱板法のような複雑なものでは なく, 非常に簡単な構造である.ただし, 測定時間が長く, あ る温度における熱伝導率を測定するためには 3 回以上の測定 が必要となり, 通常の測定に比べて約 3 倍の時間がかかると いう久点を持っている. 今後, さらに高温度領域での測定に応 用すると共に，測定時間の低減を図りたいと考えている.

\section{[謝辞]}

本研究は, 日本ケイカル侏殿からは貴重な断熱材をご提供 頂き，ここに謝意を表す.

\section{NOMENCLATURE}

A : coefficient in Eq. (14) or (15), $\mathrm{W} \cdot \mathrm{m}^{2} \cdot \mathrm{K}^{-1} \cdot \mathrm{kg}^{-1}$

$a \quad$ : defined by Eq. (6), $\mathrm{W} \cdot \mathrm{m}^{-1} \cdot \mathrm{K}^{-1}$

$B \quad$ : coefficient in Eq. (14) or (15), $\mathrm{W} \cdot \mathrm{kg} \cdot \mathrm{m}^{-4} \cdot \mathrm{K}^{4}$

d : thickness of specimen, $\mathrm{m}$

$f \quad$ : arbitrary function

$H$ : thermal conductance in the plane direction of specimen, $\mathrm{W} \cdot \mathrm{K}^{-1}$

$i \quad$ : number for denoting lattice point on $x$-axis

$j \quad$ : number for denoting lattice point on $y$-axis

$k \quad$ : number for denoting lattice point on $y$-axis

$m$ : number to identify measurement at a temperature

$n \quad$ : total number of measurement at a temperature

$Q \quad$ : amount of heat, $\mathrm{W}$

$Q_{t} \quad$ : amount of heat in direction of thickness, $\mathrm{W}$

$Q_{\text {loss }}$ : amount of heat loss from specimen and heaters, W

$r \quad$ : distance in surface of specimen, $\mathrm{m}$

$r_{e} \quad$ : distance from center to edge in specimen, $\mathrm{m}$

$S \quad$ : heat flow area, $\mathrm{m}^{2}$

$x \quad: x$-axis in three - dimensional coordinate system

$y \quad: y$-axis in three - dimensional coordinate system

$z \quad: z$-axis in three - dimensional coordinate system

$\theta \quad$ : temperature, ${ }^{\circ} \mathrm{C}$

$\theta_{\text {air }} \quad$ : atmospheric (air) temperature, ${ }^{\circ} \mathrm{C}$

$\theta_{h 1} \quad$ : temperature at center of high temperature surface of specimen, ${ }^{\circ} \mathrm{C}$

$\theta_{h 2}$ : temperature at center of contact surface between heater 1 and heater $2,{ }^{\circ} \mathrm{C}$ 
$\theta_{h 2} \quad:$ temperature at center of low temperature surface of specimen, ${ }^{\circ} \mathrm{C}$

$\theta_{h m} \quad$ : average temperature of high temperature surface of specimen, ${ }^{\circ} \mathrm{C}$

$\theta_{\text {he }} \quad$ : temperature at edge of high temperature surface of specimen, ${ }^{\circ} \mathrm{C}$

$\theta_{m} \quad$ : mean temperature decided by Eq. (15), ${ }^{\circ} \mathrm{C}$

$\Delta \theta \quad$ : differential temperature in thickness direction, ${ }^{\circ} \mathrm{C}$

$\Delta \theta_{\text {loss }}:$ differential temperature in plane direction, ${ }^{\circ} \mathrm{C}$

$\Theta \quad$ : dimensionless number defined by Eq. (7)

$\lambda \quad$ : thermal conductivity, $\mathrm{W} \cdot \mathrm{m}^{-1} \cdot \mathrm{K}^{-1}$

$\lambda_{\text {air }} \quad$ : thermal conductivity of air, $\mathrm{W} \cdot \mathrm{m}^{-1} \cdot \mathrm{K}^{-1}$

$\lambda_{c} \quad$ : coefficient in Eq. (3), $\mathrm{W} \cdot \mathrm{m}^{-1} \cdot \mathrm{K}^{-1}$

$\lambda_{g} \quad$ : thermal conductivity of gas, $\mathrm{W} \cdot \mathrm{m}^{-1} \cdot \mathrm{K}^{-1}$

$\lambda_{t}:$ thermal conductivity in direction of thickness of specimen, $\mathrm{W} \cdot \mathrm{m}^{-1} \cdot \mathrm{K}^{-1}$

$\rho \quad$ : bulk density, $\mathrm{kg} \cdot \mathrm{m}^{-3}$

\section{参考文献}

[1] JIS A 1412-1

[2] JIS A 1412-2

[3] Takahiro Ohmura; "Measurement error reduction method for thermal conductivity of thermal insulation using the GHP method", Proceedings of the 3th International Forum on Heat Transfer, November 13-15, 2012, Nagasaki Brick Hall, Nagasaki, Japan. Paper No. 043.

[4] 富村他，丸善侏，エクセルとマウスでできる熱流体の シミュレーション,(2013)

[5] 峯他, 第 53 回日本伝熱シンポジウム講演論文集 (2016), SP119 (1599)

[6] T. Ohmura, M. Onodera, and M. Naito; "Estimation Method for Attenuation Coefficient of Thermal Radiation in Thermal Insulators by Using Thermal Conductivity", Jpn. J. Appl. Phys., 50 (2011) 11RE03

[7] 大村他, 粉体工学会誌 第 46 巻 6 号 pp.461-466, (2009)

[8] 大村他, 粉体工学会誌 第46巻 11 号 pp.806-812, (2009)

[9] 大村他, 粉体工学会 2016年度 春季研究発表会 一 般-17,pp.192-193, (2016)

[Received May 22, 2017, Accepted Jul. 17, 2017] 